\title{
Graft rejection-like reactions in the early postoperative period after deep anterior lamellar keratoplasty for keratoconus: a retrospective study
}

This article was published in the following Dove Press journal: Clinical Ophthalmology

\author{
Koji Hirano' \\ Hidenori Tanaka ${ }^{1,2}$ \\ Kumiko Kato ${ }^{3}$ \\ Kaoru Araki-Sasaki ${ }^{4}$ \\ 'Department of Ophthalmology, \\ Ban Buntane Hotokukai Hospital, \\ School of Medicine, Fujita Health \\ University, Nagoya, Aichi 454-8509, \\ Japan; ' ${ }^{2}$ Department of Ophthalmology, \\ School of Medicine, Fujita Health \\ University, Toyoake, Aichi 470-I I 92, \\ Japan; ${ }^{3}$ Department of Ophthalmology, \\ Mie University School of Medicine, \\ Tsu, Mie 5/4-8507, Japan; \\ ${ }^{4}$ Department of Ophthalmology, Japan \\ Community Health Care Organization \\ Hoshigaoka Medical Center, Hirakata, \\ Osaka 573-85II, Japan
}

Background: Deep anterior lamellar keratoplasty (DALK) is indicated to correct high astigmatism in patients with keratoconus $(\mathrm{KC})$ and no evidence of Descemet's membrane rupture. However, some patients with $\mathrm{KC}$ experience graft rejection-like inflammatory reactions within 2 months (usually in the first week) after DALK. The aim of this study was to identify the characteristics and influencing factors of these reactions by reviewing the records of patients who underwent DALK or penetrating keratoplasty (PKP) for KC or other corneal problems. Methods: We retrospectively reviewed the medical records of patients who underwent DALK for $\mathrm{KC}(\mathrm{DALK} / \mathrm{KC})$, PKP for $\mathrm{KC}(\mathrm{PKP} / \mathrm{KC})$, or DALK for other corneal problems (DALK/ non-KC) at Ban Buntane Hotokukai Hospital between January 2006 and December 2015 and who were followed for more than 1 year. We collected data on the characteristics and incidence of severe inflammatory graft reactions in the early postoperative phase (ie, within 2 months after keratoplasty) and visual outcomes after these inflammatory reactions.

Results: Postoperative inflammatory reactions characterized by persistent epithelial defects, loose suture with infiltration, and vessel invasion occurred in seven of eleven DALK/KC patients, three of $50 \mathrm{DALK} /$ non-KC patients, and none of five $\mathrm{PKP} / \mathrm{KC}$ patients. These reactions were nonresponsive to topical steroids, and suture removal was required. Although a clear corneal graft in the pupillary area was obtained and best-corrected visual acuity was good after the resolution of inflammation, a risk of corneal astigmatism remained.

Conclusion: The incidence of these reactions in the early postoperative period is high after DALK for KC. These reactions do not respond well to topical steroids, and suture removal may be required, which may cause high astigmatism after the inflammation subsides. Lamellar keratoplasty should be considered carefully for patients with $\mathrm{KC}$.

Keywords: deep anterior lamellar keratoplasty, keratoconus, stromal rejection, graft rejectionlike reactions, early postoperative period, secondary corneal amyloidosis

\section{Background}

Deep anterior lamellar keratoplasty (DALK) is a surgical procedure that removes pathological corneal stroma to prepare the host bed, leaving little or no stromal tissue on Descemet's membrane (DM), followed by transplantation of donor corneal tissue. Because the host's healthy corneal endothelium is preserved, DALK has advantages over penetrating keratoplasty (PKP), such as less risk of corneal endothelial rejection, earlier discontinuation of topical corticosteroids, minor loss of endothelial cell density, earlier suture removal, and the possibility of using freeze-preserved donor corneal tissue without living cells. ${ }^{1-3}$
Department of Ophthalmology, Ba Buntane Hotokukai Hospital, School of Medicine, Fujita Health University, 6-10, Otoubashi 3-chome, Nakagawa-ku, Nagoya, Aichi 454-8509, Japan

$\mathrm{Tel}+8|5232| 8|7|$

Fax +8I 523224734

Email kojihira@fujita-hu.ac.jp 
In patients with keratoconus (KC), DALK is thought to be preferable to PKP to correct high astigmatism due to the irregular shape of the cornea, when the corneal endothelium is healthy and there is no evidence of DM rupture. However, despite the progress in surgical techniques, postoperative complications - mainly corneal epithelial, subepithelial, and stromal rejection - may lead to graft failure in DALK for KC. ${ }^{3-13}$ Stromal rejection is characterized by acute stromal edema and haze followed by vascularization confined to the area of the graft. ${ }^{46}$ Although stromal rejection is usually well controlled by topical steroids, it may still cause graft failure. ${ }^{13}$

We have previously experienced graft rejection-like inflammatory reactions within 2 months (usually in the first week) after DALK in patients with KC. The aim of this study was to identify the characteristics and influencing factors of these graft reactions by reviewing the records of patients who underwent DALK or PKP for $\mathrm{KC}$ or other corneal problems.

\section{Methods}

To identify the characteristics and influencing factors of inflammatory graft reactions after DALK, we retrospectively reviewed the medical records of patients who underwent DALK for KC (DALK/KC), PKP for KC (PKP/KC), or DALK for other corneal problems (DALK/non-KC) at Ban Buntane Hotokukai Hospital between January 2006 and December 2015 and who were followed for more than 1 year. To determine the incidence of postoperative complications and visual outcomes of DALK for KC, we compared the data from the patients who underwent DALK for other corneal problems (DALK/non-KC) in the same period. Eyes with a past history of herpetic keratitis were excluded because of the possibility of revealing unexpected inflammatory reactions after surgery. This study was approved by the Ethics Review Committee of Fujita Health University Faculty of Medicine (approval number: HM17-160) and in accordance with the Declaration of Helsinki. Written informed consent was obtained from each patient for surgery and use of the clinical records for future research.

All procedures were performed by one of the authors (KH). In moderate to advanced KC, DALK or PKP was performed due to intolerance to contact lenses and poor spectacle-corrected visual acuity. For DALK, the recipient's cornea was cut with a Hessburg-Barron trephine (Katena Products, Denville, NJ, USA) down to $350 \mu \mathrm{m}$ deep, with a diameter of either 7.00 or $7.50 \mathrm{~mm}$. A layer-by-layer technique with Sugita's hydrodissection ${ }^{14}$ and Tsubota's divideand-conquer technique ${ }^{15}$ were used for the manual removal of the stromal tissue with or without baring of DM. Exposure of DM was limited around the pupillary area, and in many cases, DM was not exposed when the removal of the stromal tissue reached a relatively smooth surface under the surgical microscope. The donor's corneal graft was prepared from the fresh sclerocorneal button with a Barron donor punch (Katena Products) with the same diameter or $0.25 \mathrm{~mm}$ larger than the recipient's trephine. DM and endothelial cells were not removed from the donor corneal button. The sclerocorneal button was preserved in $2.5 \%$ chondroitin sulfate dextran (Optisol $^{\circledR}$, Chiron Ophthalmics, Irvine, CA, USA) and was used for surgery within 10 days after the donor's death. The corneal graft was sutured to the host cornea with 8 interrupted and 16 or 24 running 10-0 nylon sutures (nylon 1404; trape spatula; Mani ${ }^{\circledR}$, Tochigi, Japan). For PKP, a trephine of either 7.00 or $7.50 \mathrm{~mm}$ in diameter was used, and the graft diameter was the same as that of the trephine or $0.25 \mathrm{~mm}$ larger; graft suture was performed as described above for DALK. Local anesthesia by sub-Tenon's injection of $2 \%$ lidocaine was administered for the surgery, except in patients with mental disorders who needed general anesthesia.

For the statistical analysis, Fisher's exact test was used to determine if postoperative complications were significantly different between DALK/KC and DALK/non-KC. The MannWhitney $U$ test was used to determine if postoperative corneal astigmatism was significantly different among the three groups (DALK/KC, PKP/KC, and DALK/non-KC). Results were considered statistically significant when $P<0.05$.

\section{Results Characteristics of patients who underwent keratoplasty}

DALK was performed in eleven eyes of eleven patients with $\mathrm{KC}(\mathrm{DALK} / \mathrm{KC}$ ), and PKP was performed in five eyes of five patients with $\mathrm{KC}(\mathrm{PKP} / \mathrm{KC})$ (Tables 1 and 2). The average age and male:female ratio of each group were 37.8 (range, 22-54) years old and 7:4, and 51.0 (range, 29-81) years old and $4: 1$, respectively. Among the five PKP/KC patients, four had a history of acute hydrops and one was converted from DALK because of DM rupture during surgery. Among the eleven DALK/KC patients, secondary corneal amyloidosis was observed in six eyes, causing irritation before surgery. Except for $\mathrm{PKP} / \mathrm{KC}$ case \#2, all patients with $\mathrm{KC}$ had allergic problems, including atopic dermatitis, allergic rhinitis, and ocular allergy. At the time of surgery, any ocular allergic disorders, including allergic conjunctivitis and vernal keratoconjunctivitis, were well controlled, either with steroid or antiallergy eye drops, in all KC patients. 
Table I Demographic and clinical characteristics of patients who underwent deep anterior lamellar keratoplasty for keratoconus

\begin{tabular}{|c|c|c|c|c|c|c|c|}
\hline Patients & Eye & $\begin{array}{l}\text { Ocular } \\
\text { conditions }\end{array}$ & $\begin{array}{l}\text { Other } \\
\text { complications }\end{array}$ & $\begin{array}{l}\text { BCVA } \\
\text { before surgery }\end{array}$ & $\begin{array}{l}\text { Intraop. } \\
\text { complications }\end{array}$ & $\begin{array}{l}\text { BCVA } \\
\text { after surgery }\end{array}$ & $\begin{array}{l}\text { Astigmatism } \\
\text { (D) }\end{array}$ \\
\hline 1 & L & $A C$ & $A D$ & 0.3 & $\mathrm{~N}$ & 1.2 & 1.00 \\
\hline 2 & L & SCA, Tri, AC & Allergic rhinitis & 0.01 & $\mathrm{~N}$ & 0.9 & 10.00 \\
\hline 3 & L & SCA, AC & Allergic rhinitis & 0.04 & $\mathrm{~N}$ & 1.0 & 4.25 \\
\hline 4 & $L$ & $A C$ & Allergic rhinitis & 0.04 & $\mathrm{~N}$ & 0.7 & 1.00 \\
\hline 5 & L & & $A D$ & 0.7 & $\mathrm{~N}$ & 0.4 & 7.00 \\
\hline 6 & $R$ & SCA, Tri, AC & $A D$ & 0.8 & $\mathrm{~N}$ & 1.0 & 15.00 \\
\hline 7 & $R$ & SCA & $A D$ & 0.01 & $\mathrm{~N}$ & 0.8 & 11.00 \\
\hline 8 & $R$ & SCA, VKC, Cat & $A D$ & 0.4 & $\mathrm{~N}$ & 1.0 & 2.75 \\
\hline 9 & L & Cat, Gla & $\begin{array}{l}\text { AD, Down syn, } \\
\text { hypothyroidism }\end{array}$ & 0.03 & $\begin{array}{l}\text { Descemet's } \\
\text { perforation }\end{array}$ & 0.08 & 4.25 \\
\hline 10 & L & Gla & Allergic rhinitis & 0.01 & $\mathrm{~N}$ & 0.8 & 1.50 \\
\hline II & $R$ & $\begin{array}{l}\text { SCA, Tri, aphakia, } \\
\text { Gla }\end{array}$ & $A D$ & Hand movement & $\mathrm{N}$ & 0.3 & 4.50 \\
\hline
\end{tabular}

Notes: Gray shadings indicate patients who revealed inflammatory graft reactions in the early postoperative period.

Abbreviations: AC, allergic conjunctivitis; AD, atopic dermatitis; BCVA, best-corrected visual acuity; Cat, cataract; Gla, glaucoma; intraop., intraoperative; L, left; N, no; R, right; SCA, secondary corneal amyloidosis; Tri, trichiasis; VKC, vernal keratoconjunctivitis; intraop., intraoperative; Down syn, Down syndrome.

In the same period, DALK was performed for 50 eyes of 45 non-KC patients (DALK/non-KC) (Table 3). The average age of the DALK/non-KC patients was 65.5 (22-89) years old, and the male:female ratio was 22:28. None of the patients in the three groups had a history of herpetic keratitis.

\section{Postoperative complications}

\section{Graft reactions within 2 months postoperatively}

As listed in Table 4, unfavorable graft reactions characterized by persistent epithelial defect (PED), suture loosening with infiltration, vessel invasion (vascularization), and graft melting were seen in seven of eleven DALK/KC patients in the early postoperative period (ie, within 2 months after DALK) (Figures 1 and 2 and Table 4, gray cells). These reactions occurred in none of five PKP/KC patients and three of 50 DALK/non-KC patients, for whom DALK was performed for corneal stromal opacity after infectious corneal ulcer, cholesterol metabolism abnormality, and unknown lipid degeneration.

Suture-related complications, graft infiltration, and vascularization in the early postoperative period did not respond well to topical steroids or therapeutic soft contact lenses. Therefore, removal of the loosened 10-0 nylon was required. After removal of the running suture, interrupted sutures were added and $0.1 \%$ betamethasone eye drops were applied until the inflammatory symptoms subsided, which took 2 weeks to 20 months (average 7.6 months) from the time of the first inflammatory sign.

\section{Stromal rejection}

Stromal rejection occurred in two of eleven DALK/KC patients (cases \#8 and \#11) at 9 and 6 months after surgery,

Table 2 Demographic and clinical characteristics of patients who underwent PKP for keratoconus

\begin{tabular}{|l|l|l|l|l|l|l|l|}
\hline Patients & Eye & $\begin{array}{l}\text { Ocular } \\
\text { conditions }\end{array}$ & $\begin{array}{l}\text { Other } \\
\text { complications }\end{array}$ & $\begin{array}{l}\text { BCVA } \\
\text { before surgery }\end{array}$ & $\begin{array}{l}\text { Intraoperative } \\
\text { complications }\end{array}$ & $\begin{array}{l}\text { BCVA } \\
\text { after surgery }\end{array}$ & $\begin{array}{l}\text { Astigmatism } \\
\text { (D) }\end{array}$ \\
\hline I & R & $\begin{array}{l}\text { PED, DM } \\
\text { rupture, Cat }\end{array}$ & AD, schizophrenia & 0.3 & N & 1.2 & 1.00 \\
\hline 2 & L & Cat & Hemolytic anemia & 0.01 & N & 0.03 & 4.75 \\
\hline 3 & R & & Allergic rhinitis & 0.03 & $\begin{array}{l}\text { Descemet's perforation } \\
\text { (DALK } \rightarrow \text { PKP) }\end{array}$ & 0.15 & 10.00 \\
\hline 4 & R & $\begin{array}{l}\text { Corneal scarring, } \\
\text { DM rupture, AC }\end{array}$ & Allergic rhinitis & 0.01 & $\mathrm{~N}$ & 0.15 & 6.75 \\
\hline 5 & L & $\begin{array}{l}\text { Corneal scarring, } \\
\text { DM rupture }\end{array}$ & AD & 0.04 & $\mathrm{~N}$ & 0.4 & 7.75 \\
\hline
\end{tabular}

Abbreviations: AC, allergic conjunctivitis; AD, atopic dermatitis; BCVA, best-corrected visual acuity; Cat, cataract; DALK, deep anterior lamellar keratoplasty; DM, Descemet's membrane; PED, persistent epithelial defect; PKP, penetrating keratoplasty. 
Table 3 Corneal disorders of eyes subjected to deep anterior lamellar keratoplasty for corneal problems other than KC

\begin{tabular}{|l|l|}
\hline Main corneal problems & Number of eyes \\
\hline Leucoma corneae & 22 \\
\hline Lattice corneal dystrophy & 9 \\
\hline Other corneal dystrophy & 5 \\
\hline Ocular pemphigoid & 4 \\
\hline Graft failure & 4 \\
\hline Secondary corneal amyloidosis other than KC & 2 \\
\hline Band-shaped keratopathy & 2 \\
\hline Corneal perforation & 2 \\
\hline
\end{tabular}

Abbreviation: KC, keratoconus.

respectively, and in case \#11, stromal edema occurred after the early graft reactions subsided. Among the 50 DALK/ non-KC patients, the same reactions were observed in one case of unknown stromal opacity 6 months after DALK.

Stromal rejection responded well to topical steroids $(0.1 \%$ betamethasone phosphate eye drops four times daily) in the three DALK patients, and the reactions subsided within a couple of weeks.

\section{Comparison of postoperative complications}

Figure 3 shows the incidence of postoperative complications in DALK/KC and DALK/non-KC patients. The incidence of postoperative complications in $\mathrm{PKP} / \mathrm{KC}$ patients is not shown because there were no such complications. Although the number of cases was small, PED, suture loosening, suture infiltration in the early postoperative period, and vascularization were more frequent among DALK/KC eyes compared with DALK/non-KC eyes $(P=0.02, P<0.001$, $P<0.001$, and $P<0.002$, respectively).

\section{Surgical outcomes (astigmatism and best- corrected visual acuity [BCVA])}

Figure 4 shows the corneal astigmatism after corneal transplantation in the three groups. Because of the difficulty of controlling corneal curvature by the early postoperative inflammatory reactions, mean astigmatism and its SD were larger in the DALK/KC group than in the other DALK cases (5.66 $\pm 4.59 \mathrm{D}$ vs $3.19 \pm 2.05 \mathrm{D}, P=0.12$ ). However, BCVA after surgery was improved in almost all cases either by using glasses or rigid contact lenses (Table 1).

\section{Secondary corneal amyloidosis patients}

One of the main features of this series of cases was the high incidence of secondary corneal amyloidosis in the DALK/ $\mathrm{KC}$ group (six of eleven DALK/KC patients).

Because of the small number of cases in this study, the occurrence of the postoperative complications could not be compared. Visual improvement was obtained after DALK in patients with or without amyloidosis (Table 1). However, the average corneal astigmatism at the last visit was 7.92 and $2.95 \mathrm{D}$ in patients with or without corneal amyloidosis, respectively. Recurrence of amyloidosis at the corneal graft or graft-host junction (observed in three cases) may cause unpredictable corneal astigmatism (Figure 2C).

Table 4 Postoperative complications after deep anterior lamellar keratoplasty for keratoconus

\begin{tabular}{|c|c|c|c|c|c|c|c|c|c|}
\hline \multirow[t]{2}{*}{ Patients } & \multicolumn{7}{|c|}{ Postoperative complications } & \multicolumn{2}{|c|}{ Postoperative period } \\
\hline & PED & $\begin{array}{l}\text { Suture } \\
\text { loosening }\end{array}$ & $\begin{array}{l}\text { Graft } \\
\text { infiltration }\end{array}$ & Vascularization & $\begin{array}{l}\text { Graft } \\
\text { melting }\end{array}$ & $\begin{array}{l}\text { Diffuse } \\
\text { graft } \\
\text { edema }\end{array}$ & $\begin{array}{l}\text { Intralayer } \\
\text { deposits }\end{array}$ & $\begin{array}{l}\text { Graft } \\
\text { reactions } \\
\text { started }\end{array}$ & $\begin{array}{l}\text { Graft } \\
\text { reactions } \\
\text { subsided }\end{array}$ \\
\hline I & $\mathrm{N}$ & $Y$ & $\mathrm{Y}$ & Y & $\mathrm{N}$ & $\mathrm{N}$ & $N$ & I day & 15 months \\
\hline 2 & $\mathrm{~N}$ & Y & $\mathrm{Y}$ & $\mathrm{N}$ & $\mathrm{N}$ & $\mathrm{N}$ & $\mathrm{N}$ & I month & I month \\
\hline 3 & $\mathrm{~N}$ & $\mathrm{Y}$ & $\mathrm{N}$ & $\mathrm{N}$ & $\mathrm{N}$ & $\mathrm{N}$ & $\mathrm{N}$ & 9 months & II months \\
\hline 4 & Y & $\mathrm{N}$ & $\mathrm{N}$ & $\mathrm{N}$ & $\mathrm{N}$ & $\mathrm{N}$ & $\mathrm{N}$ & I month & No inflammation \\
\hline 5 & Y & Y & Y & Y & Y & $\mathrm{N}$ & Y & I month & 20 months \\
\hline 6 & $\mathrm{~N}$ & $\mathrm{Y}$ & $\mathrm{N}$ & $\mathrm{N}$ & $\mathrm{N}$ & $\mathrm{N}$ & $\mathrm{N}$ & 1.5 months & No inflammation \\
\hline 7 & Y & Y & $\mathrm{Y}$ & $Y$ & $Y$ & $N$ & $Y$ & I day & 7 months \\
\hline 8 & $N$ & $Y$ & $Y$ & $Y$ & $\mathrm{~N}$ & $\begin{array}{l}\text { Y (9-month } \\
\text { postoperative) }\end{array}$ & $N$ & 4 months & 10 months \\
\hline 9 & $\mathrm{~N}$ & $Y$ & $Y$ & $Y$ & $Y$ & $N$ & $Y$ & 6 days & 9 months \\
\hline 10 & $Y$ & $Y$ & $Y$ & $Y$ & $\mathrm{~N}$ & $\mathrm{~N}$ & $N$ & 7 days & 3 months \\
\hline II & $Y$ & $Y$ & $Y$ & $Y$ & $\mathrm{~N}$ & $\begin{array}{l}\text { Y (6-month } \\
\text { postoperative) }\end{array}$ & $Y$ & 2 months & 8 months \\
\hline
\end{tabular}

Notes: Gray shadings indicate patients who revealed inflammatory graft reactions in the early postoperative period. Abbreviations: N, no; PED, persistent epithelial defect; $\mathrm{Y}$, yes. 

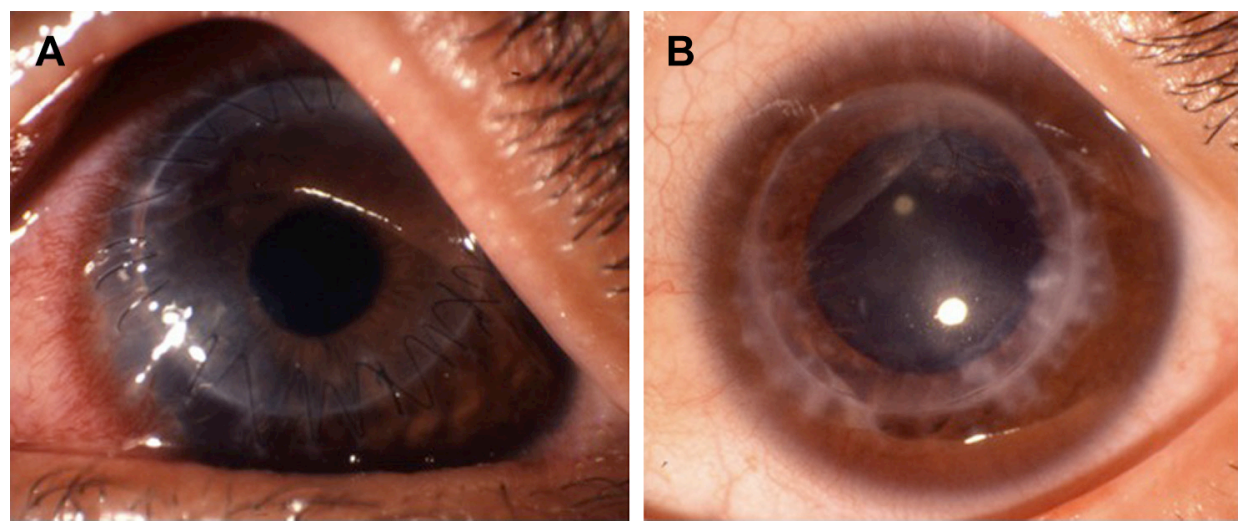

Figure I Postoperative appearance of a 32-year-old DALK/KC female patient (case \#I0).

Notes: (A) Corneal appearance at 60 days after surgery. Loosened sutures with infiltration and invaded vessels are observed. The sclera of the perilimbal area was highly injected. (B) Corneal appearance at 13 months after surgery. After the inflammation subsided, corneal opacity due to scarring and deposits around the invaded vessels were still seen.

Abbreviations: DALK, deep anterior lamellar keratoplasty; KC, keratoconus.

\section{Discussion}

In this study, we aimed to identify the characteristics and influencing factors of unfavorable graft reactions after DALK. Here, we report seven cases of corneal graft complications in the early postoperative period (ie, within 2 months of DALK for $\mathrm{KC}$ ). These reactions occurred during application of postoperative steroid eye drops and were characterized by PED, suture-related problems (suture infiltration and loosening), graft dislocation, topical infiltration, vessel invasion (vascularization), and graft melting. Because the indication and background of keratoplasty is different in $\mathrm{DALK} / \mathrm{KC}, \mathrm{PKP} / \mathrm{KC}$, and DALK/non-KC patients, we were
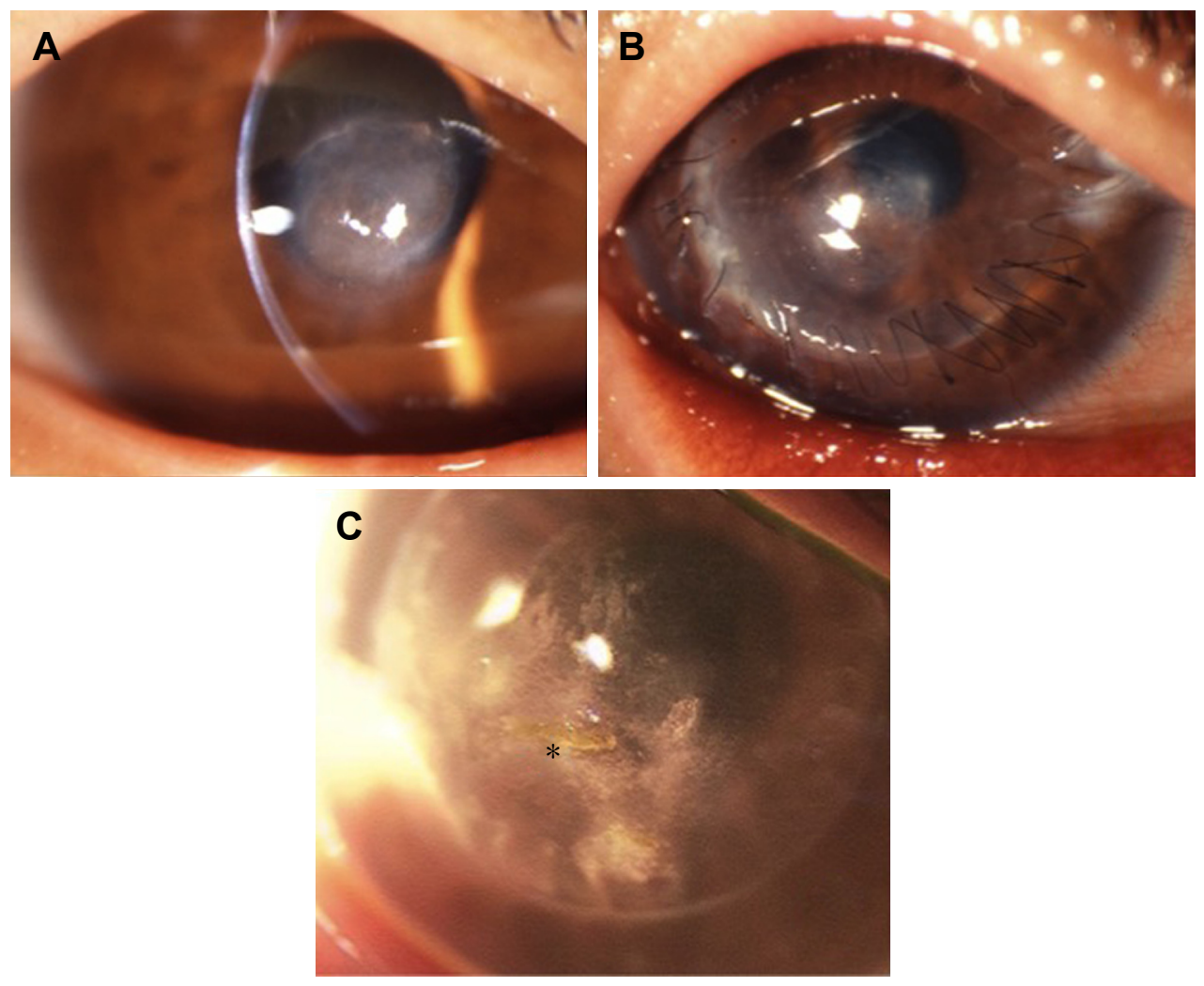

Figure 2 Corneal findings of a 37-year-old DALK/KC female patient (case \#7).

Notes: (A) Before surgery. Secondary corneal amyloidosis characteristic of KC is seen at the central area of the cornea. (B) Three months after surgery. Suture loosening with infiltration is seen. At this time, vessel invasion with ciliary injection was also seen. (C) Five years after surgery. Corneal stromal opacity due to scarring and deposits are seen in the graft, and recurrence of amyloidosis with corneal epithelial defect is also seen (asterisk).

Abbreviations: DALK, deep anterior lamellar keratoplasty; KC, keratoconus. 


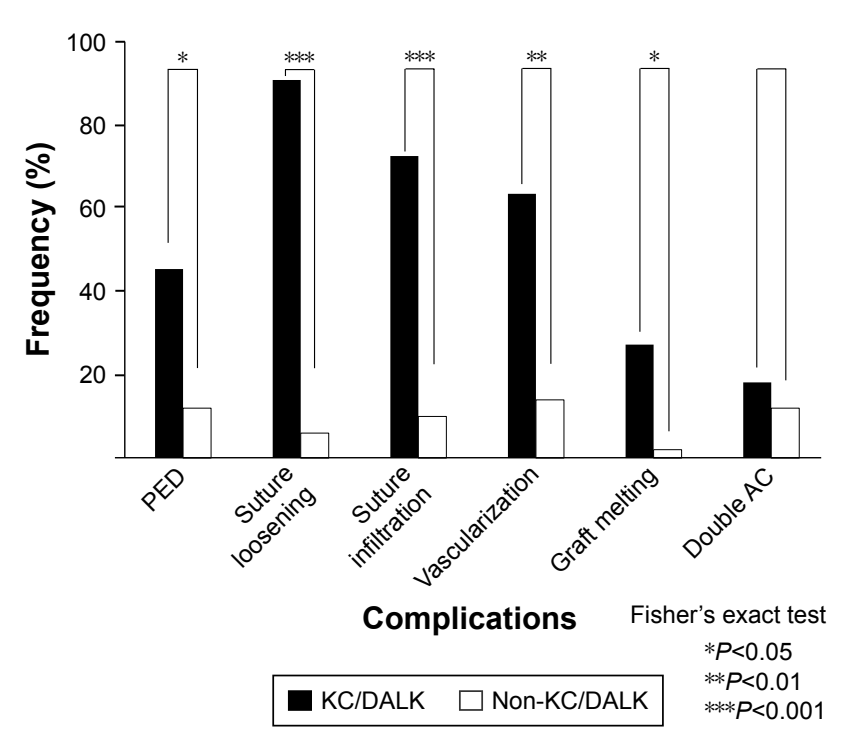

Figure 3 Incidence of postoperative complications.

Notes: The graph shows a comparison of the incidence of postoperative complications between patients with $\mathrm{KC}(\mathrm{DALK} / \mathrm{KC}, \mathrm{n}=\mathrm{II})$ and other patients (DALK/non-KC, $n=50$ ). The incidence of those complications in patients who underwent PKP for KC (PKP/KC, n=5) is not listed because they did not occur in this group.

Abbreviations: AC, anterior chamber; DALK, deep anterior lamellar keratoplasty; KC, keratoconus; PED, persistent epithelial defect; PKP, penetrating keratoplasty.

unable to compare the surgical outcomes among the three groups. Nonetheless, however, these inflammatory graft reactions in the early postoperative period seem to be specific to $\mathrm{DALK} / \mathrm{KC}$ patients.

These graft reactions in the early postoperative period resemble immune reactions, particularly corneal stromal

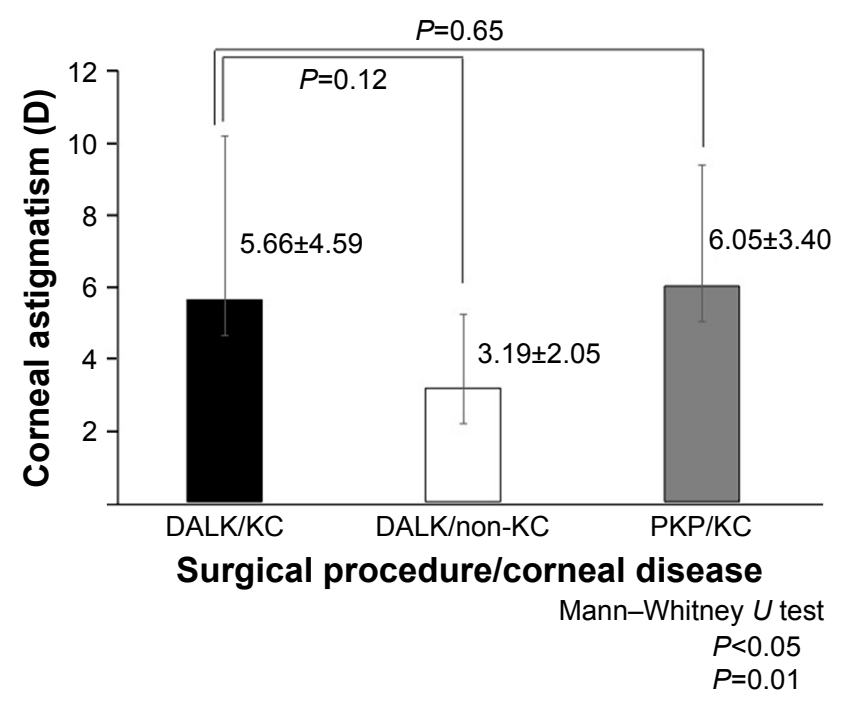

Figure 4 Corneal astigmatism more than I year after keratoplasty.

Notes: Postoperative corneal astigmatism of either DALK or PKP for KC was larger compared with DALK for corneal problems other than KC. The larger mean astigmatism and the larger SD may be due to the graft reactions both in the early postoperative period and late postoperative period (ie, stromal rejection).

Abbreviations: DALK, deep anterior lamellar keratoplasty; KC, keratoconus; PKP, penetrating keratoplasty. rejection. ${ }^{4-6}$ However, they occurred much earlier than previously reported reactions $s^{4,6,10,12}$ and were nonresponsive to topical steroids. Moreover, the reactions occurred during application of $0.1 \%$ betamethasone phosphate eye drops for suppressing postoperative inflammation. We were required to remove the sutures and to add interrupted sutures, and even so, it took patients several months to recover from the complications. The incidence of graft rejection-like reactions was $7 / 11(68.6 \%)$, which is higher than the incidence of corneal stromal rejection $(1.0 \%-23.8 \%)$, as reported previously. ${ }^{3-9,11,12}$ The reason for the higher incidence among patients with $\mathrm{KC}$ is unknown.

According to Jones et al, ${ }^{13}$ DALK for $\mathrm{KC}$ has a higher graft failure rate than PKP, which is largely explained by early failures related to coexistent atopic dermatitis and the surgeon's inexperience. Although their findings are not directly related to our cases, "co-existent atopic dermatitis" should be replaced with the host patient's background and "surgeon's inexperience" with the surgical techniques. All of the eleven DALK/KC patients in our series had allergic problems (seven patients had atopic dermatitis and the remaining four patients had allergic rhinitis). These allergic conditions may lead to postoperative graft-host immune responses ${ }^{16,17}$ even after DALK. ${ }^{11}$ Another important feature of our DALK/KC patients was the high incidence of secondary corneal amyloidosis. Postoperative inflammatory graft reactions occurred equally in patients with or without secondary corneal amyloidosis. However, the host corneal stroma, which contributes to amyloid deposition in $\mathrm{KC}$, may be related to graft rejection, even though the deposition is subclinical..$^{18,19}$

As for the surgical techniques, our manual trephination and layer-by-layer technique during removal of stromal tissue usually leave the deep stromal tissue in the graft bed, and the uniform cutting depth cannot be obtained at the host-graft junction, especially in patients with KC. It is possible that the partial discrepancy of the graft thickness and the depth of the graft bed may cause uneven tension of the running suture of the corneal graft, thereby inducing suture infiltration and loosening. ${ }^{20,21}$

Although the clarity of the corneal graft, especially in the pupillary area, could be obtained in many cases after the inflammatory reactions diminished, we have to face unpredictable corneal astigmatism. Because of the high astigmatism, contact lenses of the rigid type were needed to obtain good visual acuity in DALK/KC patients. Despite the clarity of the corneal graft, high astigmatism due to the irregularity of the graft can cause graft failure. ${ }^{22}$ In this study, four of eleven DALK/KC patients revealed corneal 
astigmatism of more than $5.0 \mathrm{D}$, which might be considered graft failure, even though good-corrected visual acuity was achieved (cases \#2, \#5, \#6, and \#7). Several reports have indicated a good postoperative course of lamellar keratoplasty with complete baring of $\mathrm{DM} ;{ }^{23-26}$ to avoid an irregular host-stromal junction, a femtosecond laser could possibly be used for the side-cut incision instead of manual trephination. ${ }^{27,28}$ Furthermore, glues could be used instead of nylon sutures to minimize inflammation after surgery. ${ }^{29}$ However, because of the unpredictable graft reactions due to the pathologic corneal stroma, its indication for patients with $\mathrm{KC}$ should be reconsidered carefully.

The main limitation of this study was the single-center study design. Additional information from other institutions is needed to clarify the etiology of graft rejection-like reactions after DALK. This could help devise a method to prevent such reactions in patients with $\mathrm{KC}$.

\section{Conclusion}

Inflammatory graft reactions characterized by PED, loosening of the suture with infiltration, infiltration in the wider area of the graft, vessel invasion, and graft melting may occur in the early postoperative period after DALK for KC. These reactions do not respond well to topical steroids, and suture removal is required. Although clear corneal graft at the pupillary area was obtained and BCVA was good after the resolution of inflammation, there remains a risk of unpredictable corneal astigmatism. These reactions may be caused by the patient's background, that is, coexistent atopic dermatitis or allergic rhinitis, younger age, complication of secondary corneal amyloidosis, and the surgical technique without exposing DM, especially at the peripheral graft bed. Because of these corneal stromal reactions, the indication of lamellar keratoplasty or DALK for patients with $\mathrm{KC}$ should be considered carefully.

Unfavorable graft reactions occurred in the early postoperative period after DALK for KC and may be specific to patients with $\mathrm{KC}$.

\section{Data sharing statement}

The datasets used and/or analyzed during the current study are available from the corresponding author on reasonable request.

\section{Acknowledgments}

We thank Prof Masayuki Horiguchi, MD, $\mathrm{PhD}$, from the Department of Ophthalmology, Fujita Health University for encouraging us to perform keratoplasty in patients with various corneal disorders and for his invaluable suggestions during the preparation of this manuscript. The study was supported by a grant from the Fujita Gakuen Research Fund.

\section{Author contributions}

$\mathrm{KH}$ performed all the surgical procedures in this study and wrote the manuscript. KH and HT analyzed and interpreted the data on surgical complications and outcomes. KK statistically compared the incidence of surgical complications among the three groups. KA-S made critical comments to the manuscript and gave input regarding the pathological changes in the corneal stroma of patients with keratoconus. All authors contributed to data analysis, drafting and revising the article, gave final approval of the version to be published, and agree to be accountable for all aspects of the work.

\section{Disclosure}

The authors report no conflicts of interest in this work.

\section{References}

1. Reinhart WJ, Musch DC, Jacobs DS, Lee WB, Kaufman SC, Shtein RM Deep anterior lamellar keratoplasty as an alternative to penetrating keratoplasty. Ophthalmology. 2011;118(1):209-218.

2. Coombes AG, Kirwan JF, Rostron CK. Deep lamellar keratoplasty with lyophilised tissue in the management of keratoconus. Br JOphthalmol. 2001;85(7):788-791.

3. Al-Torbak AA, Al-Motowa S, Al-Assiri A, et al. Deep anterior lamellar keratoplasty for keratoconus. Cornea. 2006;25(4):408-412.

4. Al-Torbak A, Malak M, Teichmann KD, Wagoner MD. Presumed stromal graft rejection after deep anterior lamellar keratoplasty. Cornea. 2005;24(2):241-243.

5. Olson EA, Tu EY, Basti S. Stromal rejection following deep anterior lamellar keratoplasty: implications for postoperative care. Cornea. 2012;31(9):969-973.

6. Watson SL, Tuft SJ, Dart JK. Patterns of rejection after deep lamellar keratoplasty. Ophthalmology. 2006;113(4):556-560.

7. Noble BA, Agrawal A, Collins C, Saldana M, Brogden PR, Zuberbuhler B. Deep anterior lamellar keratoplasty (DALK): visual outcome and complications for a heterogeneous group of corneal pathologies. Cornea. 2007;26(1):59-64.

8. Söğütlü Sari E, Kubaloğlu A, Ünal M, et al. Penetrating keratoplasty versus deep anterior lamellar keratoplasty: comparison of optical and visual quality outcomes. Br J Ophthalmol. 2012;96(8):1063-1067.

9. Javadi MA, Feizi S, Yazdani S, Mirbabaee F. Deep anterior lamellar keratoplasty versus penetrating keratoplasty for keratoconus: a clinical trial. Cornea. 2010;29(4):365-371.

10. Kawashima M, Mochizuki H, Kawakita T, Hatoh S, Shimazaki J, Yamada M. Presumed stromal graft rejection after automated lamellar therapeutic keratoplasty: case report. J Med Case Rep. 2007;1:10.

11. Feizi S, Javadi MA, Javadi F, Jafarinasab MR. Deep anterior lamellar keratoplasty in keratoconic patients with versus without vernal keratoconjunctivitis. J Ophthalmic Vis Res. 2015;10(2):112-117.

12. Fontana L, Parente G, Tassinari G. Clinical outcomes after deep anterior lamellar keratoplasty using the big-bubble technique in patients with keratoconus. Am J Ophthalmol. 2007;143(1):117-124.

13. Jones MN, Armitage WJ, Ayliffe W, Larkin DF, Kaye SB; NHSBT Ocular Tissue Advisory Group and Contributing Ophthalmologists (OTAG Audit Study 5). Penetrating and deep anterior lamellar keratoplasty for keratoconus: a comparison of graft outcomes in the United Kingdom. Invest Ophthalmol Vis Sci. 2009;50(12):5625-5629. 
14. Sugita J, Kondo J. Deep lamellar keratoplasty with complete removal of pathological stroma for vision improvement. Br J Ophthalmol. 1997; 81(3):184-188.

15. Tsubota K, Kaido M, Monden Y, Satake Y, Bissen-Miyajima H, Shimazaki J. A new surgical technique for deep lamellar keratoplasty with single running suture adjustment. Am J Ophthalmol. 1998;126(1): $1-8$.

16. Lyons CJ, Dart JK, Aclimandos WA, Lightman S, Buckley RJ. Sclerokeratitis after keratoplasty in atopy. Ophthalmology. 1990;97(6): 729-733.

17. Tomita M, Shimmura S, Tsubota K, Shimazaki J. Postkeratoplasty atopic sclerokeratitis in keratoconus patients. Ophthalmology. 2008; 115(5):851-856.

18. Araki-Sasaki K, Ando Y, Nakamura M, et al. Lactoferrin Glu561Asp facilitates secondary amyloidosis in the cornea. Br J Ophthalmol. 2005; 89(6):684-688.

19. Araki-Sasaki K, Osakabe Y, Fujita K, Miyata K, Hirano K. Collagen fiber changes related to keratoconus with secondary corneal amyloidosis. Int Med Case Rep J. 2018;11:193-199.

20. Li S, Wang T, Bian J, Wang F, Han S, Shi W. Precisely controlled side cut in femtosecond laser-assisted deep lamellar keratoplasty for advanced keratoconus. Cornea. 2016;35(10):1289-1294.

21. Ardjomand N, Hau S, McAlister JC, et al. Quality of vision and graft thickness in deep anterior lamellar and penetrating corneal allografts. Am J Ophthalmol. 2007;143(2):228-235.
22. Price MO, Thompson RW Jr, Price FW Jr. Risk factors for various causes of failure in initial corneal grafts. Arch Ophthalmol. 2003;121(8): 1087-1092.

23. Tan DT, Anshu A, Parthasarathy A, Htoon HM. Visual acuity outcomes after deep anterior lamellar keratoplasty: a case-control study. $\mathrm{Br} J$ Ophthalmol. 2010;94(10):1295-1299.

24. MacIntyre R, Chow SP, Chan E, Poon A. Long-term outcomes of deep anterior lamellar keratoplasty versus penetrating keratoplasty in Australian keratoconus patients. Cornea. 2014;33(1):6-9.

25. Kubaloglu A, Sari ES, Unal M, et al. Long-term results of deep anterior lamellar keratoplasty for the treatment of keratoconus. $\mathrm{Am} \mathrm{J}$ Ophthalmol. 2011;151(5):760-767.e1.

26. Han DC, Mehta JS, Por YM, Htoon HM, Tan DT. Comparison of outcomes of lamellar keratoplasty and penetrating keratoplasty in keratoconus. Am J Ophthalmol. 2009;148(5):744-751.e1.

27. Gonzalez A, Price MO, Feng MT, Lee C, Arbelaez JG, Price FW Jr. Immunologic rejection episodes after deep anterior lamellar $\mathrm{z}$ : incidence and risk factors. Cornea. 2017;36(9):1076-1082.

28. Chen Y, Hu DN, Xia Y, Yang L, Xue C, Huang Z. Comparison of femtosecond laser-assisted deep anterior lamellar keratoplasty and penetrating keratoplasty for keratoconus. BMC Ophthalmol. 2015; 15:144.

29. Cho SY, Kim MS, Oh SJ, Chung SK. Comparison of synthetic glues and 10-0 nylon in rabbit lamellar keratoplasty. Cornea. 2013;32(9): $1265-1268$.
Clinical Ophthalmology

\section{Publish your work in this journal}

Clinical Ophthalmology is an international, peer-reviewed journal covering all subspecialties within ophthalmology. Key topics include: Optometry; Visual science; Pharmacology and drug therapy in eye diseases; Basic Sciences; Primary and Secondary eye care; Patient Safety and Quality of Care Improvements. This journal is indexed on

\section{Dovepress}

PubMed Central and CAS, and is the official journal of The Society of Clinical Ophthalmology (SCO). The manuscript management system is completely online and includes a very quick and fair peer-review system, which is all easy to use. Visit http://www.dovepress.com/ testimonials.php to read real quotes from published authors. 